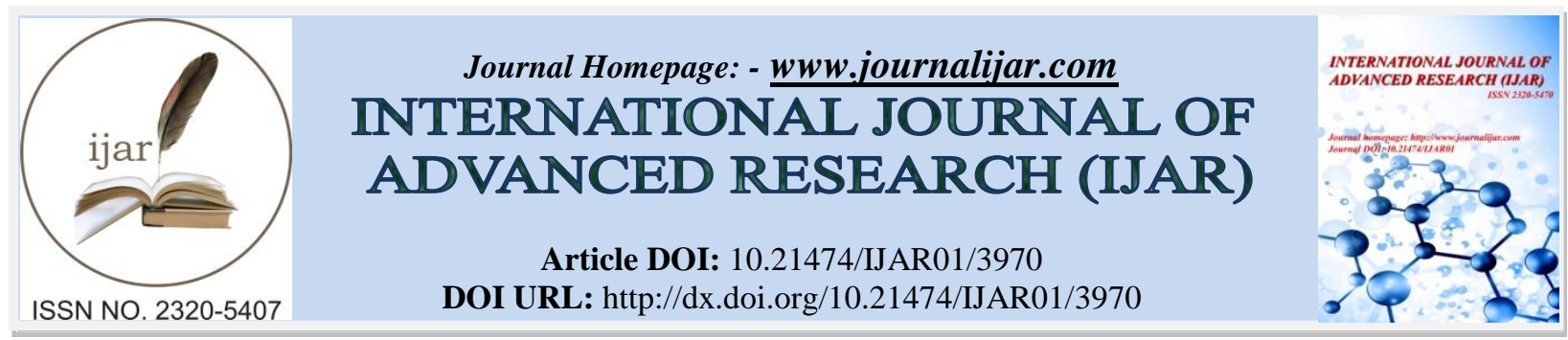

RESEARCH ARTICLE

\title{
PLASMA OSTEOPONTIN AS A NOVEL DIAGNOSTIC BIOMARKER FOR EARLY DETECTION OF HEPATOCELLULAR CARCINOMA.
}

Mohamed El-Tantawy Ibrahim ${ }^{1}$, Mohamed Ahmed Mohamed ${ }^{1}$ and Hanaa El-Sayed bayomy ${ }^{2}$.

1. Internal Medicine Department, Faculty of Medicine, Benha University, Benha, Egypt.

2. Public Health and Community Medicine Department, Faculty of Medicine, Benha University, Benha, Egypt.

\section{Manuscript Info}

Manuscript History

Received: 18 February 2017

Final Accepted: 07 March 2017

Published: April 2017

Key words:-

Hepatocellular carcinoma, HCV,

Osteopontin, Alpha-fetoprotein.

\section{Abstract}

Background: Hepatocellular carcinoma (HCC) is a worldwide major health problem, with increasing prevalence and poor prognosis. As regard Egypt, HCC increased due to high prevalence of Hepatitis C virus (HCV) infection. Osteopontin (OPN) is a phosphorylated glycoprotein, which play an important role in the pathogenesis of different inflammatory and fibrotic processes. Recently, OPN has developed as a promising new biomarker for HCC.

Aim: This study aimed to assess the value of OPN as a biomarker for early detection of $\mathrm{HCC}$ in $\mathrm{HCV}$ positive patients with cirrhosis.

Method: This study included 60 persons, divided into 4 groups each of them included 15 persons; normal persons as a control, HCV positive patients without cirrhosis, HCV positive patients with cirrhosis, HCV positive patients with cirrhosis and complicated with HCC. For all groups, History, physical examination and radiological findings were collected. OPN and AFP levels were detected by ELISA.

Results: HCC patients were more likely males with a mean age 61 years. . OPN level was significantly higher in the HCC group than other groups $(\mathrm{P}<0.001)$. In $\mathrm{HCV}$ positive patients $\mathrm{OPN}$ was more sensitive than AFP, but in cirrhotic patients AFP was more sensitive and specific, while both were equal in detection of patient with HCC.

Conclusion: Plasma Osteopontin level seemed to be a biomarker for the detection of HCC in cirrhotic patients with HCV.

Copy Right, IJAR, 2017,. All rights reserved.

\section{Introduction:-}

Worldwide, Hepatocellular carcinoma (HCC) is one of the most common malignancies. The 5-years survival rate for HCC is low, with a range of $4-6 \%$ in different countries [1].

The incidence and mortality rates are heterogonous, with increased mortality rate in last year's according to the World Health Organization (WHO) [2]. In Egypt, HCC has become the second most common in patient with cirrhosis in male and the sixth most common in female [3].

In $80-90 \%$ of cases, HCC develops on cirrhotic liver or inflamed liver [4]. Generally, about $54 \%$ of cases due to Hepatitis B virus (HBV) infection, $31 \%$ related to HCV infection and about $15 \%$ related to other causes [5]. The 
standard curative treatment for HCC is Hepatic resection and transplantation or resection in patients with good liver function [6].

Less than $20 \%$ of patients are diagnosed in late stage when the curative therapy can't be performed [7].

Alpha-Fetoprotein (AFP) has been widely used as a serological marker for HCC but has limitation and is consider as inadequate screening test [8]. AFP might present in high level in HCV positive patients due to hepatic fibrosis and necro- inflammation due to the course of the disease and unrelated to HCC [9]. So, the guidelines of the American and the European association of liver diseases have excluded AFP as a screening for HCC [8].

Also, about 20\% of HCC don't secrete AFP even with large size [10].The fibrolamellar HCC, which is common in young Caucasian females and metastasis to the lymph nodes, present without elevation in AFP [11].

Osteopontin (OPN) is a glycophosphoprotein, which was first described in 1979 [12]. OPN was detected in healthy individuals, cancer patients as well as patients with inflammation [13].

OPN was found in many liver diseases such as acute liver failure, nonalcoholic fatty liver disease, alcoholic liver disease, chronic hepatitis B and chronic hepatitis C [14]. In HCC, OPN binds to cancer cells and endothelial cells resulting in increased cell survival, cell migration and angiogenesis [15].

This study aimed to investigate the role of OPN in early detection of $\mathrm{HCC}$ in $\mathrm{HCV}$ positive patients.

\section{Patients and Methods:-}

This study was conducted in Benha university hospital and included sixty individuals. These were divided into four groups each of them had fifteen individuals; group (I) healthy controls, group (II) HCV positive patients without cirrhosis, group (III) HCV positive patients with cirrhosis and group (IV) HCV positive patients with cirrhosis and developed HCC on top.

The studied individuals were recruited from the outpatient clinic, hematology and oncology unit and hepatology unit of the Internal Medicine Department in Benha University hospital, Qualubeyia Governorate, Egypt. The field work was carried out over the period between the beginning of September 2015 to the end of March 2016. For every patient, a written consent was obtained. An approval from the Research Ethics Committee in Benha Faculty of Medicine was obtained to conduct this work. Patient with HCC and other malignancies or HBV positive patients were excluded from the study.

For all subjects, complete history was obtained and physical examination was carried out. The diagnosis of cirrhosis was established on the basis of clinical, laboratory and imaging (ultrasonography and computed tomography).

The diagnosis of HCC was defined according to the non-invasive criteria of the European Association for the Study of the Liver (EASL) and the European Organization for Research and Treatment of Cancer (EORTC) guidelines [16].

For all subjects, blood samples were collected as fasting venous samples in plastic tubes containing Ethylene Diamine Tetra Acetic acid (EDTA), and isolated plasma and serum samples were separated and stored at $-80^{\circ} \mathrm{C}$. The collected samples were used to assess the levels of Alanine Aminotransferase (ALT), Aspartate Aminotrnsferase (AST), total bilirubin, serum albumin, serum creatinine and Prothrombin Time (PT). Viral markers were confirmed using Polymerase Chain Reaction for HCV Ribonucleic Acid (PCR HCV RNA). All laboratoty investigations were carried out in the Clinical Pathology Department, Benha university hospital.

Plasma OPN was determined using an Enzyme-Linked Immune Sorbent Assay (ELISA) kit according to the manufactures instructions. Each sample was examined in duplicate and the mean was used for data analysis. AFP was determined using the ELISA kit.

\section{Statistical Analysis:-}

The collected data were summarized in terms of mean \pm SD for quantitative data and frequency and percentage for categorical data. Chi square test was used to compare categorical variables while ANOVA (F) test was used to compare quantitative variables with LSD test for multiple comparisons. The Pearson correlation coefficient ( $\mathrm{r}$ ) was 
used to assess the correlations between estimated parameters. The diagnostic performance of OPN and AFP for $\mathrm{HCV}$ positive patients, cirrhotic patients and HCC patients were examined and the best cut off points and the corresponding sensitivity, specificity, Positive Predictive Value (PPV), Negative Predictive Value (NPV), positive Likelihood Ratio (+LR), negative Likelihood Ration (-LR), accuracy and the Area Under the Curve (AUC) were estimated. A P-value $<0.05$ was considered statistically significant. All statistical analysis was carried out using the computerized Statistical Package for Social Science (SPSS; Version 20.0 for Windows, SPSS Inc., Chicago, IL).

\section{Results:-}

The clinical and laboratory data for the studied groups are shown in Table 1. HCC patients had higher age (61.13 \pm 6.88 years) and were more likely to be males $(73.3 \%)$ compared to other groups. However these differences were not significant. Liver function tests, hemoglobin concentration, platelets count and creatinine level showed significant differences between the different study groups $(\mathrm{P}<0.001)$.

The mean serum level of AFP $(115.27 \pm 79.27 \mathrm{ng} / \mathrm{dl})$ and the mean plasma level of OPN $(878.67 \pm 536.72 \mathrm{ng} / \mathrm{dl})$ were significantly higher in $\mathrm{HCV}$ positive patients with cirrhosis and $\mathrm{HCC}$ compared to the normal group, HCV positive patients and HCV positive patients with Cirrhosis $(\mathrm{P}<0.001)$.

Table 2 shows the diagnostic performance of AFP and OPN for HCV positive patients, HCV positive patients with cirrhosis and $\mathrm{HCV}$ positive patients with cirrhosis and $\mathrm{HCC} v s$. the normal group.

OPN had a higher AUC as a diagnostic biomarker for HCV positive patients than AFP $(0.85 ; 95 \%$ Confidence Interval (CI) 0.69-1.0 vs. 0.74; 0.56-0.93) (Fig. 1).

In comparison between patients with $\mathrm{HCV}$ positive patients with Cirrhosis versus normal group, AUC for OPN was (0.96; 0.90-1.0) while AUC of AFP was $(0.99 ; 0.97-1.0)$ (Fig. 2). When patients with HCV positive, Cirrhosis and HCC compared to normal group, the AUC for OPN was the same as that yielded by AFP (1.0;1.0-1.0) (Fig. 3).

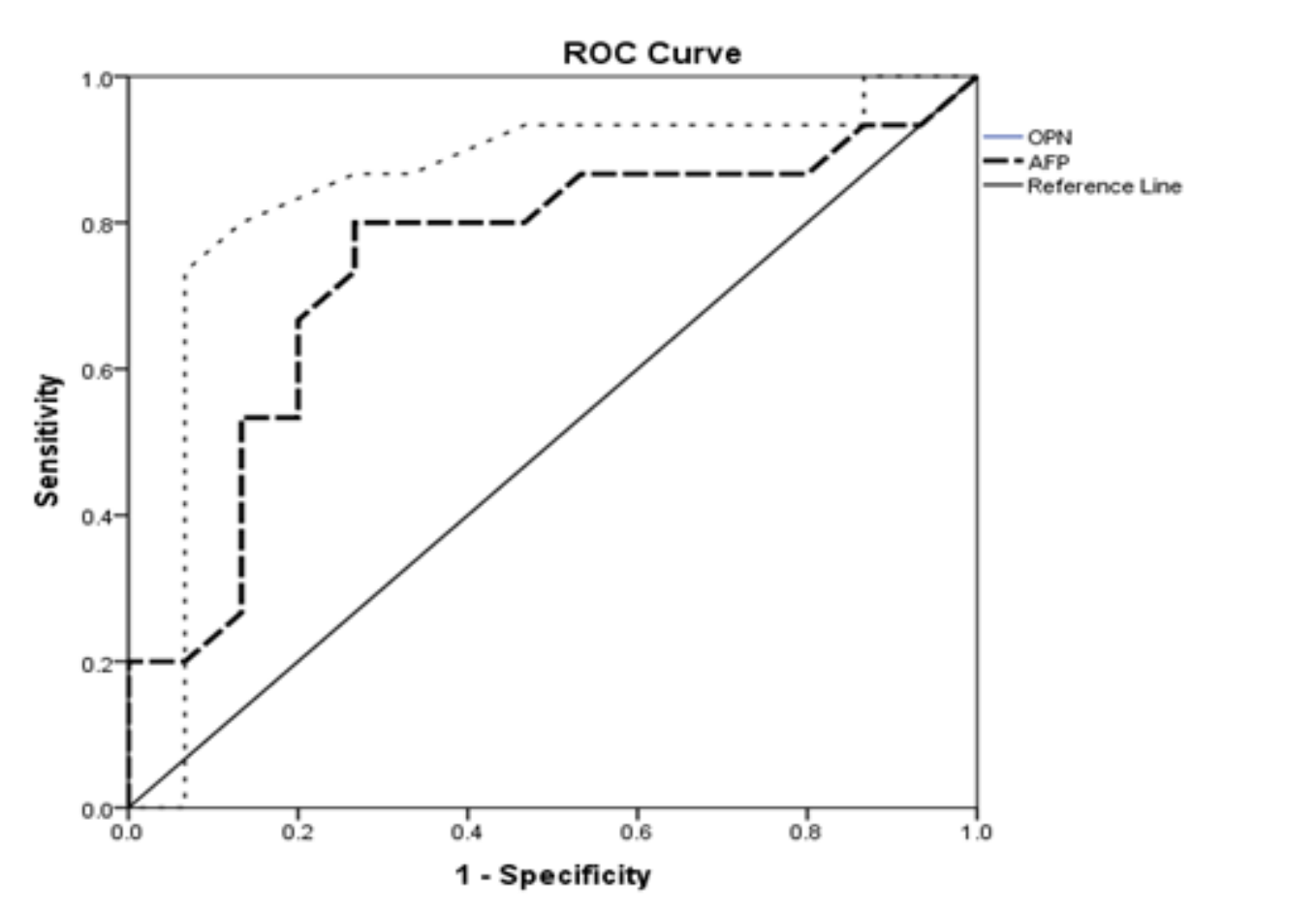

Fig. 1:- Receiver Operating Characteristic (ROC) curve for OPN and AFP in the diagnosis of early stages of HCV vs. normal. Area under ROC Curve (AUC) for OPN was 0.85 while for AFP was 0.74 . 


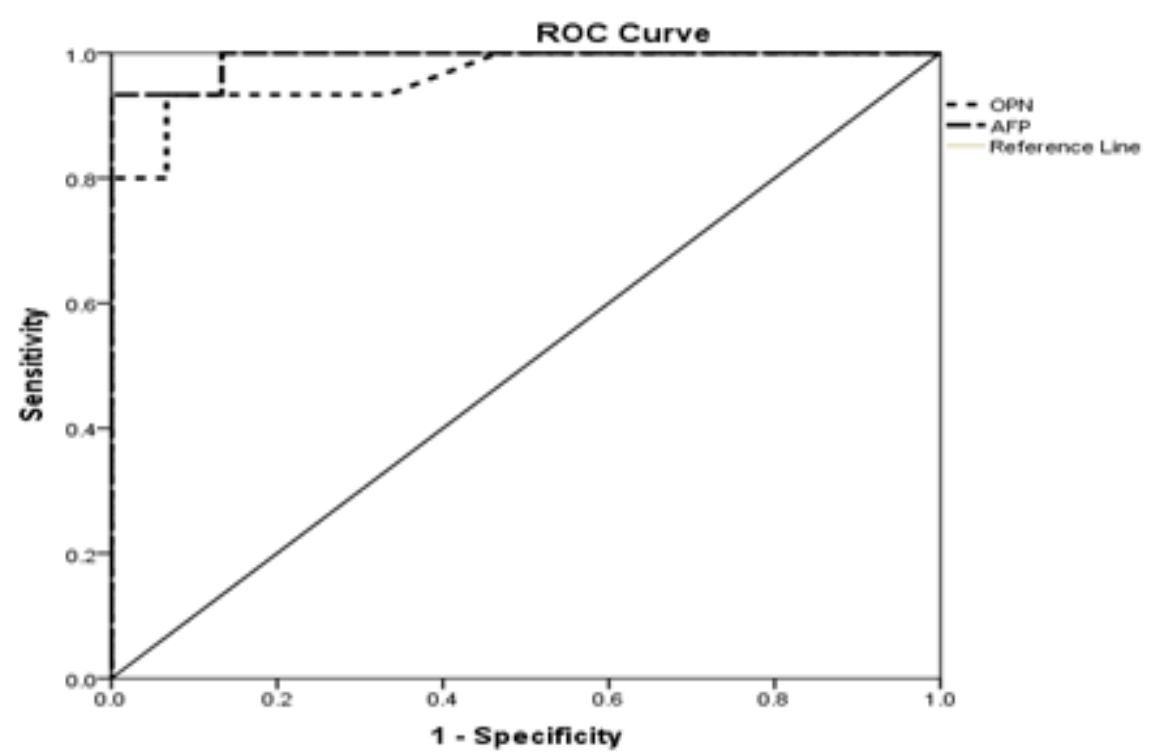

Fig. 2:- Receiver Operating Characteristic (ROC) curve for OPN and AFP in the diagnosis of HCV positive patients with Cirrhosis vs. normal. Area under ROC Curve (AUC) for OPN was 0.96 while for AFP was 0.99.

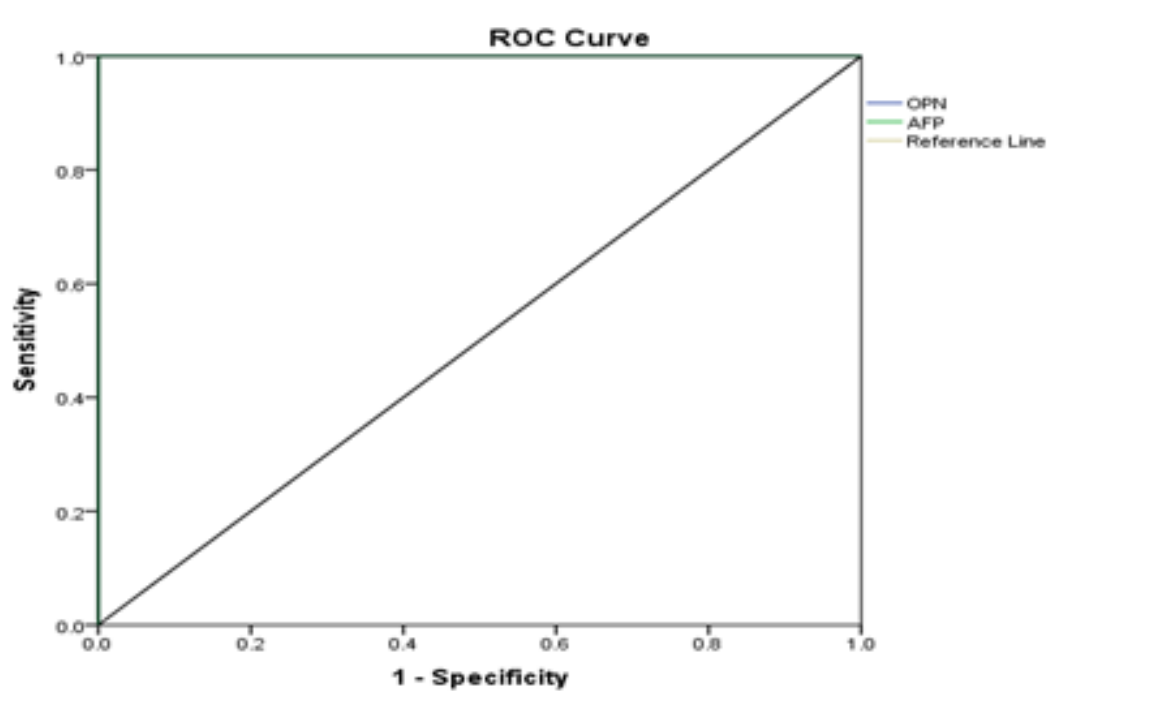

Fig. 3:- Receiver Operating Characteristic (ROC) curve for OPN and AFP in the diagnosis of early stages HCV positive patients with Cirrhosis and HCC vs. normal. AUC for OPN was 1.0 while for AFP was 1.0. 
Table 1:- Clinical and laboratory characteristics of the studied groups.

\begin{tabular}{|c|c|c|c|c|c|c|}
\hline \multirow[t]{2}{*}{ Variable } & \multicolumn{4}{|c|}{ Mean \pm SD } & \multirow{2}{*}{$\begin{array}{c}\mathrm{F} \\
\text { test }\end{array}$} & \multirow[t]{2}{*}{ P value } \\
\hline & Normal & $\begin{array}{c}\text { HCV positive } \\
\text { patients }\end{array}$ & $\begin{array}{c}\text { HCV positive } \\
\text { patients with } \\
\text { Cirrhosis }\end{array}$ & $\begin{array}{c}\text { HCV positive patients } \\
\text { with Cirrhosis and } \\
\text { HCC }\end{array}$ & & \\
\hline $\begin{array}{c}\text { Age } \\
\text { (years) }\end{array}$ & $55.47 \pm 14.26$ & $52.2 \pm 13.88$ & $58.47 \pm 7.73$ & $61.13 \pm 6.88$ & 1.77 & 0.164 \\
\hline $\begin{array}{c}\text { Sex } \\
\text { Male }(\%) \\
\text { Female }(\%)\end{array}$ & $\begin{array}{l}9(60.0) \\
6(40.0)\end{array}$ & $\begin{array}{c}10(66.7) \\
5(33.3)\end{array}$ & $\begin{array}{l}9(60.0) \\
6(40.0)\end{array}$ & $\begin{array}{c}11(73.3) \\
4(26.7)\end{array}$ & ${ }^{\wedge} 0.81$ & 0.85 \\
\hline ALT (iu/l) & $30.73 \pm 2.15$ & $33.13 \pm 4.26$ & $50.53 \pm 10.93^{\mathrm{ab}}$ & $54.4 \pm 9.23^{\mathrm{ab}}$ & 37.99 & $<0.001$ \\
\hline AST (iu/l) & $32.73 \pm 2.55$ & $34.2 \pm 4.09$ & $52.6 \pm 7.98^{\mathrm{ab}}$ & $52.67 \pm 7.53^{\mathrm{ab}}$ & 51.32 & $<0.001$ \\
\hline HB (gm/dl) & $12.75 \pm 0.85$ & $12.67 \pm 0.94$ & $10.95 \pm 0.71^{\mathrm{ab}}$ & $9.49 \pm 1.06^{\mathrm{abc}}$ & 44.81 & $<0.001$ \\
\hline $\begin{array}{c}\text { Platelets } \\
\left(\mathrm{x} 10^{3} / \mathrm{mm}^{3}\right)\end{array}$ & $288.47 \pm 21.12$ & $246.87 \pm 49.72^{a}$ & $138.47 \pm 24.5^{\mathrm{ab}}$ & $111.47 \pm 17.48^{\mathrm{abc}}$ & 112.9 & $<0.001$ \\
\hline $\begin{array}{l}\text { Bilirubin } \\
(\mathrm{mg} / \mathrm{dl})\end{array}$ & $0.84 \pm 0.09$ & $0.82 \pm 0.12$ & $1.43 \pm 0.35^{\mathrm{ab}}$ & $2.12 \pm 0.33^{\mathrm{abc}}$ & 89.61 & $<0.001$ \\
\hline $\begin{array}{c}\text { PT } \\
\text { (in seconds) }\end{array}$ & $12.03 \pm 0.74$ & $12.23 \pm 0.90$ & $14.13 \pm 1.60^{\mathrm{ab}}$ & $15.8 \pm 1.47^{\mathrm{abc}}$ & 30.98 & $<0.001$ \\
\hline $\begin{array}{l}\text { Creatinine } \\
(\mathrm{mg} / \mathrm{dl})\end{array}$ & $0.88 \pm 0.14$ & $0.90 \pm 0.14$ & $1.01 \pm 0.20^{\mathrm{a}}$ & $1.09 \pm 0.18^{\mathrm{ab}}$ & 5.27 & $<0.001$ \\
\hline $\begin{array}{c}\text { Albumin } \\
(\mathrm{gm} / \mathrm{dl})\end{array}$ & $3.98 \pm 0.15$ & $3.84 \pm 0.12$ & $3.13 \pm 0.27^{\mathrm{ab}}$ & $2.5 \pm 0.23^{\mathrm{abc}}$ & 172.3 & $<0.001$ \\
\hline AFP (ng/dl) & $2.28 \pm 0.77$ & $3.11 \pm 1.03$ & $9.88 \pm 3.15$ & $115.27 \pm 79.27^{\mathrm{abc}}$ & 29.04 & $<0.001$ \\
\hline OPN (ng/dl) & $49.6 \pm 18.71$ & $77.0 \pm 18.43$ & $214.0 \pm 92.63$ & $878.67 \pm 536.72^{\mathrm{abc}}$ & 30.58 & $<0.001$ \\
\hline
\end{tabular}

$\mathrm{a}=$ significant $v s$. normal group; $\mathrm{b}=$ significant $v s$. HCV group; $\mathrm{c}=$ significant $v s$. HCV+ Cirrhosis group; ${ }^{\wedge}=\mathrm{chi}$ square test

Table 2:- Diagnostic performance of OPN and AFP for HCC, Cirrhosis and HCV group vs. the normal group.

\begin{tabular}{|c|c|c|c|c|c|c|c|c|c|c|c|}
\hline $\begin{array}{l}\text { Tumor } \\
\text { marker }\end{array}$ & Group & AUC & $\begin{array}{c}95 \% \\
\text { CI }\end{array}$ & $\begin{array}{c}\text { Cut } \\
\text { off } \\
\text { point }\end{array}$ & $\begin{array}{c}\text { Sensitivity } \\
(\%)\end{array}$ & $\begin{array}{c}\text { Specificity } \\
(\%)\end{array}$ & $\begin{array}{l}\text { PPV } \\
(\%)\end{array}$ & $\begin{array}{l}\text { NPV } \\
(\%)\end{array}$ & $\begin{array}{c}\text { Accuracy } \\
(\%)\end{array}$ & $+\mathrm{LR}$ & -LR \\
\hline \multirow[t]{3}{*}{ OPN } & $\begin{array}{c}\text { HCV } \\
\text { positive } \\
\text { patients } \\
\text { vs. normal }\end{array}$ & $\begin{array}{l}0.8 \\
47\end{array}$ & $\begin{array}{c}0.69- \\
1.0\end{array}$ & 53.0 & 86.7 & 73.3 & $\begin{array}{c}76 . \\
5\end{array}$ & 84.6 & 80.0 & $\begin{array}{c}3.2 \\
8\end{array}$ & $\begin{array}{c}0.1 \\
8\end{array}$ \\
\hline & $\begin{array}{c}\text { Cirrhotic } \\
\text { patients } \\
\text { vs. normal }\end{array}$ & $\begin{array}{l}0.9 \\
64\end{array}$ & $\begin{array}{c}0.90- \\
1.0\end{array}$ & 74.5 & 93.3 & 93.3 & $\begin{array}{c}93 . \\
3\end{array}$ & 93.3 & 93.3 & $\begin{array}{c}13 . \\
9\end{array}$ & $\begin{array}{c}0.0 \\
7\end{array}$ \\
\hline & $\begin{array}{c}\text { HCC } \\
\text { patients } \\
\text { vs. normal } \\
\end{array}$ & 1.0 & $\begin{array}{l}1.0- \\
1.0\end{array}$ & 53 & 100 & 73.3 & $\begin{array}{c}93 . \\
8\end{array}$ & 100 & 96.7 & $\begin{array}{c}3.7 \\
5\end{array}$ & 0.0 \\
\hline \multirow[t]{3}{*}{ AFP } & $\begin{array}{c}\text { HCV } \\
\text { positive } \\
\text { patients } \\
\text { vs. normal }\end{array}$ & $\begin{array}{l}0.7 \\
44\end{array}$ & $\begin{array}{l}0.56- \\
0.93\end{array}$ & 2.4 & 80.0 & 73.3 & $\begin{array}{c}75 . \\
0\end{array}$ & 78.6 & 76.7 & $\begin{array}{c}3.0 \\
3\end{array}$ & $\begin{array}{c}0.2 \\
7\end{array}$ \\
\hline & $\begin{array}{c}\text { Cirrhotic } \\
\text { patients } \\
\text { vs. normal }\end{array}$ & $\begin{array}{c}0.9 \\
9\end{array}$ & $\begin{array}{c}0.97- \\
1.0\end{array}$ & 3.2 & 100 & 86.7 & $\begin{array}{c}78 . \\
9\end{array}$ & 100 & 86.7 & $\begin{array}{c}7.5 \\
2\end{array}$ & 0.0 \\
\hline & $\begin{array}{c}\text { HCC } \\
\text { patients } \\
\text { vs. normal }\end{array}$ & 1.0 & $\begin{array}{l}1.0- \\
1.0\end{array}$ & 2.5 & 100 & 73.3 & $\begin{array}{c}93 . \\
8\end{array}$ & 100 & 96.7 & $\begin{array}{c}3.7 \\
5\end{array}$ & 0.0 \\
\hline
\end{tabular}

AUC $=$ Area under ROC Curve; $\mathrm{CI}=$ Confidence Interval; PPV= Positive Predictive Value; NPV= Negative Predictive Value; $+\mathrm{LR}=$ positive Likelihood Ration; $-\mathrm{LR}=$ negative Likelihood Ratio 


\section{Discussion:-}

HCC is the most common malignancy in Egypt, where there is the high prevalence of HCV infection all over the world. In Egypt, about 14\% of the population has chronic HCV infection [17].

The delayed diagnosis of HCC leads to poor response to treatment. About two thirds of patients are discovered in advanced stages of disease [18]. AFP is the most common tumor marker in HCC, whom compared with other tumor markers [19].

The results of this study showed that the mean age of HCC patients was $61.13 \pm 6.88$ years, which was older than the mean age of the other studied groups. This could be due to the duration of the underlying liver disease. Along with this, Di Bsiceglie added that HCC was reported to develop in the fifth decade [20]. In this study males were the predominant gender in all studied groups. They represented $73.3 \%$ of patients with HCC. This also was found by Lehman et al, who stated that HCC incidence in males was greater than females in Egypt. This also was found worldwide as HCC in males was 1.3- 3.6 times more than in females [21].

In the current study, the liver function tests including ALT, AST, bilirubin, Serum albumin and PT showed significant differences between HCV positive patients with cirrhosis group and HCV positive patients with cirrhosis and $\mathrm{HCC}$ compared to the normal group and $\mathrm{HCV}$ positive patients group $(\mathrm{P}<0.001)$. This goes in agreement with Lopez, who reported that abnormal liver functions were more frequent in HCC patients than chronic hepatitis [22].

The mean serum level of AFP in HCV positive patient with cirrhosis and HCC was significantly higher than the other groups. This also was found by Simão et al, who found that AFP levels were significantly higher in cirrhotic patients with HCC than in those without HCC $(\mathrm{P}<0.001)$. However, AFP levels were not correlated with the ChildPugh classes [23]. Moreover, Bruix and Sherman stated that AFP had a suboptimal performance and was considered an inadequate screening test for HCC and the association of AFP and ultrasound findings increased the costs and the number of false positives and seemed to have no advantage in practice [8].

Recently other tumor markers were included with AFP in the diagnosis of HCC. OPN is one of suggested tumor markers for $\mathrm{HCV}$ positive patients with cirrhosis and HCC. OPN was expressed in many tumors and correlated with tumor grading and staging of malignancy [24].

The results of this study showed that OPN levels in HCC patients were significantly higher than in HCV positive patients, patient with cirrhosis and healthy persons. This was supported by previous studies, who suggested the use of OPN as a diagnostic biomarker for HCC $[25,26]$. Shang et al added that OPN was markedly elevated in the plasma of HCC patients, and had been identified as a diagnostic biomarker, which could also improve AFP performance in HCC surveillance among patients with HBV or HCV related cirrhosis [27].

In this study we used ROC curve to compare the diagnostic performance of AFP and OPN; between the control group and each of the other three groups and this resulted in:

* OPN was more sensitive than AFP in the diagnosis of HCV positive patients.

- AFP was more specific and sensitive in the diagnosis of cirrhotic patients.

* OPN and AFP had the same specificity and sensitivity in the diagnosis of HCC patients.

So, as a biomarker, in HCV positive patients OPN was better than AFP, but in cirrhotic patients AFP was better, while both were comparable in the detection of patients with HCC.

Kawashima et al stated that the hepatic expression of OPN was first found in Kupffer cells, stellate cells and macrophages in inflammatory and necrotic areas, in rats with carbon tetrachloride intoxication [28].

Shang et al reported that OPN has a good sensitivity in AFP negative HCC, indicating OPN as a better marker in the early stage of HCC, so the role of OPN and AFP in HCC diagnosis is complementary [27].

Also Salema et al reported a significant elevation of plasma OPN levels in HCC patients than HCV patients' levels and lower levels in normal population [29]. Zhang et al mentioned that the plasma OPN levels positively correlated with the serum AFP concentration in HCC patients [30]. 
In contrast to the current study, Zekri et al reported that there was no significant increase in the level of OPN in HCC patients than those with chronic HCV liver diseases [31].

\section{Conclusion:-}

According to this study, the plasma OPN level was higher in chronic HCV patient and HCC patients. So, OPN might be used as a biomarker for the detection of HCV infection and the early detection of HCC in HCV patients with cirrhosis.

\section{Reference:-}

1. El-Garem H, H Abdel-Hafez, A Foaud, W Al Akel and M Eldien Atia: Tissue biomarkers in the early detection of hepatocellular carcinoma among Egyptian patients with chronic hepatitis C: A possible genetic profile. Br. J. Med. Med. Res. 2013, 3(4): 1858-1870.

2. Berrino F, De Angelis R, Sant M, Rosso S, Lasota MB and Coebergh JW: EUROCARE Working group. Survival for eight major cancers and all cancers combined for European adults diagnosed in 1995-99: results of the EUROCARE-4 study. Lancet Oncol. 2007; 8(9):773-83.

3. Omar A, Abou-Alfa GK, Khairy A and Omar H: Risk factors for developing hepatocellular carcinoma in Egypt. Chin. Clin. Oncol. 2013; 2(4): 43.

4. Bessa SS, Elwan NM and Suliman GA: Clinical significance of plasma osteopontin level in Egyptian patients with hepatitis C virus-related hepatocellular carcinoma. Arch. Med. Res. 2010; 41(7):541-7.

5. Hassan MM, Hwang LY, Hatten CJ, Swaim M, Li D, Abbruzzese JL: Risk factors for hepatocellular carcinoma: synergism of alcohol with viral hepatitis and diabetes mellitus. Hepatology. 2002; 36:1206-13.

6. Liovet JM and Beaugrand M: Hepatocellular carcinoma: present status and future prospects. J. Hepatol. 2003; 38(Suppl 1): S136-S149.

7. Szalay F: Hepatitis C virus infection and hepatocarcinogenesis. Orv. Hetil. 2010, 151(38): 1524-9.

8. Bruix J and Sherman M: Management of hepatoclellular carcinoma: an update. Hepatology. 2011; 53(3):10202.

9. Di Bisceglie AM: Issues in screening and surveillance for hepatocellular carcinoma. Gastroenterology 2004, 127(5 Suppl 1): S104-7.

10. Ryder SD: Guidelines for the diagnosis and treatment of hepatocellular carcinoma (HCC) in adults. Gut. 2003; 52 (suppl. III): 1-8.

11. El-Serag HB and Davila JA: Is fibrolamellar carcinoma different from hepatocellular carcinoma? A US population-based study. Hepatology. 2004; 39(3): 798-803.

12. Senger DR, Wirth DF and Hynes RO: Transformed mammalian cells secrete specific proteins and phosphoproteins. Cell. 1979; 16(4): 885-93.

13. Yang M, A Ramachandran, HM Yan, BL Woolbright and BL Copple: Osteopontin is an initial mediator of inflammation and liver injury during obstructive cholestasis after bile duct ligation in mice. Toxicol. Lett. 2014, 224(2): 186-195.

14. Zhao L, Li T, Wang Y, Pan Y, Ning H, Hui X: Elevated plasma osteopontin level is predictive of cirrhosis in patients with hepatitis infection. International journal of clinical practice. 2008; 62(7): 1056-62.

15. Tajima K, R Ohashi, Y Sekido, T Hida and T Nara: Osteopontin-mediated enhanced hyaluronan binding induces multidrug resistance in mesothelioma cells. Oncogene. 2010, 29(13): 1941-51.

16. European Association for the Study of the Liver (EASL) and European Organization for Research and Treatment of Cancer (EORTC): EASL-EORTC Clinical Practice Guidelines: Management of hepatocelular carcinoma. J. Hepatol. 2012; 56(4):908-43.

17. El-Zayadi AR, HM Badran, S Shawky, S Emara, A El-Bareedy and M Sobhi: Effect of surveillance for hepatocellular carcinoma on tumor staging and treatment decisions in Egyptian patients. Hepatol. Int. 2010, 4(2): 500-6.

18. Akahoshi $\mathrm{H}, \mathrm{N}$ Taura, T Ichikawa, H Miyaaki and M Akiyama: Differences in prognostic factors according to viral status in patients with hepatocellular carcinoma. Oncol. Rep. 2010, 23(5): 1317-23.

19. Lopez JB: Recent development in the first detection of hepatocellular carcinoma. Clin. Biochem. Rev. 2005; 26(3): 65-79.

20. Di Bisceglie AM: Epidemiology and clinical presentation of hepatocellular carcinoma. J. Vasc. Interv. Radiol. 2002; 13(9 Pt 2):S169-71. 
21. Lehman EM, Soliman AS, Ismail K, Hablas A, Seifeldin IA, Ramadan M and El-Hamzawy H: Patterns of hepatocellular carcinoma incidence in Egypt from a population- based cancer registry. Hepatol. Res. 2008; 38(5):465- 73.

22. Lopez JB: the value of liver function tests in hepatocellurlar carcinoma. Mabysian J. pathol. 1996; 18(2): 95-9.

23. Simão A, Madaleno J, Silva N, Rodrigues F, Caseiro P, Costa JN and Carvalho A: Plasma osteopontin is a biomarker for the severity of alcoholic liver cirrhosis, not for hepatocellular carcinoma screening. BMC Gastroenterology 2015; 15:73.

24. Sun HY, Y Li, K Guo, XN Kang, C Sun and YK Liu: Identification of metastasis-related osteopontin expression and glycosylation in hepatocellular carcinoma. Zhonghua Gan Zang Bing Za Zhi 2011, 19(12): 9047.

25. Kim J, SS Ki, SD Lee, CJ Han and YC Kim: Elevated plasma osteopontin levels in patients with hepatocellular carcinoma. Am. J. Gastroenterol. 2006, 101(9): 2051-9.

26. Abu El Makarem MA, Abdel-Aleem A and Ali A: Diagnostic significance of plasma osteopontin in hepatitis C virus related hepatocellular carcinoma. Ann. Hepatol. 2011; 10(3): 296-305.

27. Shang S, Plymoth A, Ge S, Feng Z, Rosen HR and Sangrajrang S: Identification of osteopontin as a novel marker for early hepatocellular carcinoma. Hepatology. 2012; 55(2): 483-90.

28. Kawashima R, Mochida S, Matsui A, You LU, Tu ZY and Ishikawa K: Expression of osteopontin in Kupffer cells and hepatic macrophages and Stellate cells in rat liver after carbon tetrachloride intoxication: a possible factor for macrophage migration into hepatic necrotic areas. Biochem. Biophys. Res. Commun. 1999; 256(3):527-31.

29. Mona Salema, Sahar Abdel Attia, Maisa El Razikyb, Samar Kamal Darweeshb and Marwa El Sharkawya: Clinical Significance of Plasma Osteopontin Level as a Biomarker of Hepatocellular Carcinoma Gastroenterology Research. 2013; 6(5):191-199.

30. Zhang H, Ye QH, Ren N, Zhao L, Wang YF, Wu X and Sun HC: The prognostic significance of preoperative plasma levels of osteopontin in patients with hepatocellular carcinoma. J. Cancer Res. Clin. Oncol. 2006; 132(11):709-717.

31. Zekri ARN, AA Bahnassy, HMA El-Din, HM Morsy, S Shaarawy, NZ Moharram and SS Daoud: Serum levels of $\beta$-catenin as a potential marker for genotype 4/hepatitis C-associated hepatocellular carcinoma. Oncol. Rep. 2011, 26(4): 825-31. 